\title{
Potencial for Natural Forest Regeneration from Seed Bank in an Upper Paraná River Floodplain, Brazil
}

\author{
João Batista Campos ${ }^{1 *}$ and Maria Conceição de Souza ${ }^{2}$ \\ ${ }^{1}$ Instituto Ambiental do Paraná; Av. Bento Munhoz da Rocha Neto, 16; 87.030-010; Maringá - Paraná - Brazil. \\ ${ }^{2}$ Universidade Estadual de Maringá/PEA; Av. Colombo 5.790; 87.020-900; Maringá - Paraná - Brazil
}

\begin{abstract}
The historical process of deforestation was analyzed to evaluate the regeneration potential of forests from soil seed bank of Porto Rico island $\left(53^{\circ} 15^{\prime} \mathrm{W}\right.$ and $\left.22^{\circ} 45^{\prime} \mathrm{S}\right)$ in the upper Paraná river floodplain. Remnant forest fragments were identified and measured and the structure of arboreous vegetation and the composition of the seed bank of the forests and grassland of the island were evaluated. Results showed a fast process of deforestation with critical levels of forest: the remaining twice fragments represented only $5.98 \%$ of the total surface of the island. Disturbance by cattle raised on the island continuously degraded the fragments (backward succession), while expansion of areas with pasture favored severe impoverishment of the seed banks flora. The latter factor, soil compaction, and characteristics of seeds of existing arboreous species in the bank suggested that the immediate reestablishment of vegetation was more conditioned to introduction processes of seeds (by rain and "flood seed") than by stock of seeds in the bank.
\end{abstract}

Key words: Deforestation, alluvial forest, floodplain, Paraná river, Brazil

\section{INTRODUCTION}

The present form of soil use by man is incompatible with the sensitive interrelations of physical and chemical biotic components of ecosystems. Pressure on production by unsustainable use and expansion of soil has already destroyed important ecosystems. Since the agricultural frontiers of areas with the best production capacity have been depleted, immediate interest has been renewed towards areas considered peripheral to the production process. Floodplains are, thus, in evidence. The fragility and physical and chemical characteristics of floodplains (Junk et al., 1989) provide a differentiated behavior on vegetation (Neiff, 1986; Campos et al., 2000), but few studies exist on the floristic structure and composition and, in a special way, on successional dynamics and seed banks.

Knowledge of the composition of seed banks is important to understanding the vegetation dynamics. Once an area is disturbed either by natural or human causes, the vegetation structure will be conditioned chiefly by seeds of species present in the soil. Thus, the manner in which the process of natural succession will develop in the area may be predicted (Guevara and GómezPompa, 1976). In areas severely disturbed by man (in intensity, frequency and space), what would be the role of the seed bank in the reestablishment process of arboreous vegetation? Will the forest reestablish itself from its seed banks when disturbances stop? To answer these questions, we evaluated the structure of arboreous vegetation

\footnotetext{
* Author for correspondence
} 
present in remnant forest fragments within an area heavily disturbed by man. We analyzed the composition and the characteristics of arboreous species of the seed bank of pasture and forest fragments in the Porto Rico Island, upper Paraná river floodplain.

\section{MATERIALS AND METHODS}

\section{Study area}

Porto Rico island is situated in the upper Paraná river floodplain $\left(53^{\circ} 15^{\prime} \mathrm{W}, 22^{\circ} 45^{\prime} \mathrm{S}\right.$, altitude $230 \mathrm{~m}$ ) (Fig.1). The climate is tropical-subtropical with hot summers, mean temperature of the hottest month is over $22^{\circ} \mathrm{C}$ (yearly average $22^{\circ} \mathrm{C}$ ) and average annual rainfall of $1,500 \mathrm{~mm}$. It is subjected to periodical flooding owing to its flat surface and to its insertion within the floodplain (Agostinho and Zalewski, 1996). The area is also inserted within the phytoecological region of pluvial forest or semideciduous seasonal forest with local vegetation classified as semideciduous seasonal alluvial forest (IBGE, 1992). Currently the island is extensively used for cattle raising.

\section{Analysis of the deforestation process}

Evaluation of deforestation and spatial quantification of vegetation were undertaken by metrical aerial photographs of 1952 (scale 1:25,000), 1965 (scale 1: 40,000), 1970 (scale 1: 50,000), 1980 (scale 1: 25,000) and 1996 (scale 1: $50,000)$. Photos were analyzed and interpreted by stereoscope and geo-referred by cartographic basis. Mapping of identified classes was made by overlays of transparent paper, fed to SGI/INPE program with area calculation and delimitation of perimeters on photos. COREL-DRAW 7.0 was employed for the final edition of photo-maps (Campos, 1999).

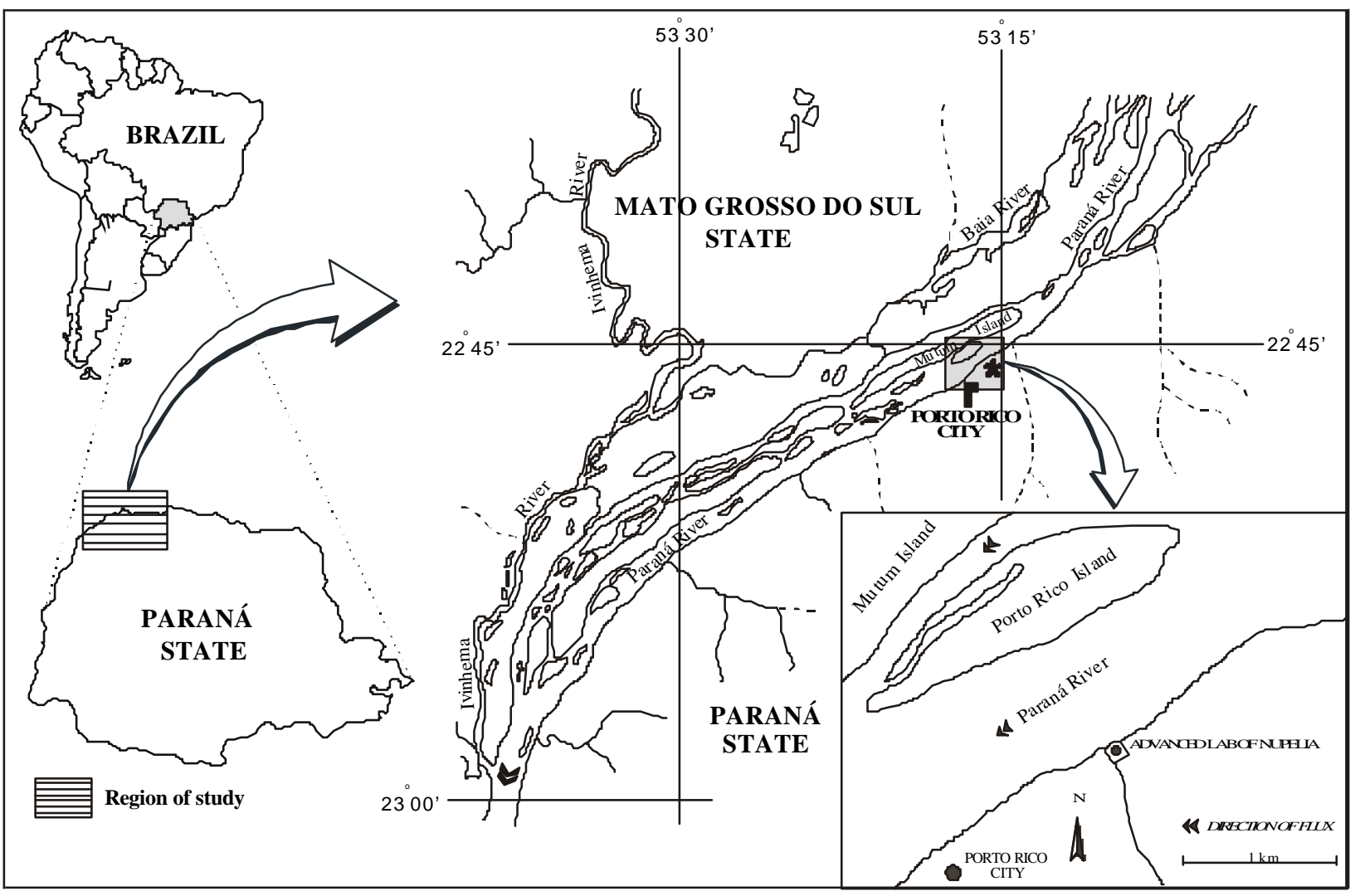

Figure 1 - Location of the study area in the high Paraná river floodplain, Brazil. 


\section{Floristic and phytosociological survey}

In the remnant forests (Forest 1, Forest 2 and Forest 3), vegetation was evaluated by a phytosociological survey based on continuous divisions (Müeller-Dombois and Ellenberg, 1974). In Forest 1, 2 and 3, the total area sampled amounted to $4,110 \mathrm{~m}^{2}, 4,500 \mathrm{~m}^{2}$ and $1,350 \mathrm{~m}^{2}$ respectively. Sampled areas were subdivided into $15 \times 10 \mathrm{~m}$ rectangles. All individuals with circumference at breast height $(\mathrm{CBH}) 15 \mathrm{~cm}$ were sampled. Individuals included dead and standing branched vegetation in which at least one branch had the established $\mathrm{CBH}$. Phytosociological parameters were obtained from field survey and analyzed using the FITOPAC 1.4 program. We estimated density, dominance and absolute and relative frequency. Data furnished importance value (IV) and Shannon-Weaner diversity (H') (Müeller-Dombois and Ellenberg, 1974; Matteucci and Colma, 1982).

In the evaluation of the serum stage and disturbance level of vegetation, sampled species were classified at following successional categories: pioneer, secondary and climax, according to literature (Budowski, 1963, 1965, 1966; Denslow, 1980; Kageyama 1992) and according to personal field observations.

\section{Analysis of seed bank}

The chosen areas for analysis comprised the grassland and the forest fragments described above. Two collectors were employed for the collection of samples of seed bank from the soil. They were made of metal, L-shaped, measuring 40 $\mathrm{x} 40 \mathrm{~cm}$ and $20 \times 20 \mathrm{~cm}$, both $5 \mathrm{~cm}$ deep. Twenty samples were collected from Forest 1 and 2 by the $40 \times 40 \mathrm{~cm}$ collectors, with litters together with 5 $\mathrm{cm}$ of mineral soil, totaling $3.2 \mathrm{~m}^{2}$ of sampled area per fragment. In Forest 3, nine samples were collected with the $40 \times 40 \mathrm{~cm}$ collector, with litter together with $5 \mathrm{~cm}$ of mineral soil and 9 samples of 5 to $10 \mathrm{~cm}$, totaling $1.44 \mathrm{~m}^{2}$ of sampled area per depth.

In the grassland, already deforested since 1970, a $200 \times 400 \mathrm{~m}$ area was chosen. $20 \times 20 \mathrm{~cm}$ collectors with litter randomly collected 39 samples, with litter together with $5 \mathrm{~cm}$ of mineral soil and 39 samples at a depth from 5 to $10 \mathrm{~cm}$, totaling an area of $1.56 \mathrm{~m}^{2}$ per depth. Samples of forest areas were collected on the 18 - 19 April 1996; samples of pasture were collected on the 30
April and 1 May 1996. Samples were conditioned in dark plastic bags and taken to the vegetation house of the Ecology Park of the State University of Maringá, Maringá PR Brazil. The vegetation house is made of steel bars, PVC transparent covering and ray ban sides. Samples were spread in the vegetation house in $2 \mathrm{~cm}$ layers to germinate in previously sterilized beds. Reference beds were kept for possible contamination. Watering was due daily.

After seed germination, shoots were collected, counted, identified and fixed in alcohol $40 \%$. Soil was periodically worked up to stimulate germination. Last harvest was done on the $20^{\text {th }}$ December 1996 when experiment ended. Plants were grouped in arboreous, gramineous, cyperaceous and other categories. Arboreous categories were specifically selected for this research.

\section{Analysis of data from seed bank}

DCA (Detrended Correspondence Analysis) was employed to analyze data of seed bank (Hill and Gauch, 1980), to evaluate grouping of arboreous species and other categories in the bank seed and their relations with the environments studied. With regard to arboreous species, relations with the environment and vertical distribution of seed in the soil cross section were evaluated. Data input were the number of seeds germinated $/ \mathrm{m}^{2}$. PC-ORD 2.0 was employed for analysis.

\section{RESULTS}

The deforestation process in the Porto Rico island may be perceived in the photo-maps elaborated from aerial photographs available (Fig. 2). In 1952 , the island seemed to have had its original vegetation. Out of its total area, some $92.08 \%$ was covered by forest and remaining percentage shared by colonization vegetation $(5.74 \%)$ and by sand bank at the start of its formation and colonization (2.18\%). Between 1952 and 1965, more than half of the island was deforested $(57.87 \%)$. The original forest occupied only $42.13 \%$. The deforestation process maintained the same pace between 1965 and 1970 (Table 1). 
Table 1 - Historical process of deforestation and percentage of forest in the Porto Rico island (1952-1996).

\begin{tabular}{cccccc}
\hline Year & $\begin{array}{c}\text { Total area } \\
\text { (ha) }\end{array}$ & $\begin{array}{c}\text { Remaining forest } \\
\text { (ha) }\end{array}$ & $\begin{array}{c}\text { Deforested area } \\
\text { (ha) }\end{array}$ & $\begin{array}{c}\text { Annual } \\
\text { deforestation } \\
\text { (ha) }\end{array}$ & $\begin{array}{c}\text { Forest covering } \\
(\%)\end{array}$ \\
\hline 1952 & 101.31 & 93.92 & - & - & 92.08 \\
1965 & 113.71 & 47.91 & 65.80 & 5.06 & 42.13 \\
1970 & 111.87 & 26.78 & 85.09 & 3.86 & 23.94 \\
1980 & 107.55 & 18.28 & 89.27 & 0.42 & 17.00 \\
1996 & 103.12 & 6.17 & 96.95 & 0.48 & 5.89 \\
\hline
\end{tabular}

\section{Floristic and phytosociological survey}

Gramineae (Panicum spp., Setaria spp., Paspalum spp. and others), cyperaceae (Cyperus spp.) and other herbaceous species (e.g., Lippia alba, Ageratus conyzoides, Solanum spp., Phyllanthus spp., Amaranthus lividus Sida rhombifolia, Heliotropium spp.) were recorded in pasture area. In the survey of the arboreous extract of Forest 1, a higher number of individuals was registered. However, Forest 3 has the highest density per hectare (Table 2). The area/density ratio, indicating the average area occupied by each specimen, showed that Forest 1 had individuals with higher diameter, and that Forest 3 individuals had the least diameter. Species diversity was higher for Forest 3, even though the sampled area was smaller than that of the others.

The most important species in the three fragments was Cecropia pachystachya. Other species had differentiated participation (Fig. 3a and Annex 1).

Concerning successional categories, pioneer species predominated in Forest 2 and secondary species in Forests 1 and 3. The latter had a more equitable distribution of percentage participation of successional categories in total IV composition. This fact indicated a lower disturbance level and/or more advanced serum stage than in the other forests (Fig. 3b).

Table 2 - Sampled area, phytosociological parameters and diversity (Shannon-Weaner index) for forest fragments

\begin{tabular}{|c|c|c|c|c|c|c|c|}
\hline $\begin{array}{c}\text { Forest } \\
\text { fragments }\end{array}$ & $\begin{array}{l}\text { Sampled } \\
\text { area }\left(\mathrm{m}^{2}\right)\end{array}$ & $\begin{array}{l}\text { Number of } \\
\text { individuals }\end{array}$ & $\begin{array}{c}\text { Density } \\
\text { (ind.ha }^{-1} \text { ) }\end{array}$ & $\begin{array}{c}\text { Basal area } \\
\left(\mathbf{m}^{2} \cdot \mathbf{h a}^{-1}\right)\end{array}$ & $\begin{array}{c}\text { Relation } \\
\text { basal } \\
\text { area/density }\end{array}$ & $\begin{array}{c}\text { Number of } \\
\text { species }\end{array}$ & $\begin{array}{c}\text { Diversity } \\
\left(\mathbf{H}^{\prime}\right)\end{array}$ \\
\hline Floresta 1 & 4,110 & 544 & 1,295 & 38.28 & 0.0295 & 38 & 2.24 \\
\hline Floresta 2 & 4,500 & 424 & 942 & 27.04 & 0.0287 & 20 & 1.97 \\
\hline Floresta 3 & 1,350 & 222 & 1,652 & 27.37 & 0.0166 & 26 & 2.48 \\
\hline
\end{tabular}

Table 3 - Arboreous species, plant categories and average number of germinated seeds per square meter, with their respective confidence intervals $( \pm)$ for different environments and depths ( $\mathrm{L}=$ litter).

\begin{tabular}{|c|c|c|c|c|c|c|}
\hline \multirow[t]{3}{*}{ Species/categories } & \multicolumn{6}{|c|}{ Environments (germinated seeds. ${ }^{-2}$ ) } \\
\hline & \multirow{2}{*}{$\begin{array}{c}\text { Forest 1 } \\
(\mathrm{n}=\mathbf{2 0})\end{array}$} & \multirow{2}{*}{$\begin{array}{c}\begin{array}{c}\text { Forest } 2 \\
(\mathrm{n}=\mathbf{2 0})\end{array} \\
\end{array}$} & \multicolumn{2}{|c|}{ Forest $3(n=9)$} & \multicolumn{2}{|c|}{ Pasture $(n=39)$} \\
\hline & & & $\mathrm{L}+5 \mathrm{~cm}$ & $5-10 \mathrm{~cm}$ & $\mathrm{~L}+5 \mathrm{~cm}$ & $5-10 \mathrm{~cm}$ \\
\hline Cecropia pachystachya Trec. & $892^{ \pm 687}$ & $822^{ \pm 536}$ & $1747^{ \pm 2215}$ & $565^{ \pm 414}$ & $28^{ \pm 14}$ & $34^{ \pm 27}$ \\
\hline Celtis iguanaea (Jacq.) Sargent. & - & $18^{ \pm 12}$ & - & - & - & - \\
\hline Croton urucurana Baill. & $97^{ \pm 53}$ & $93^{ \pm 79}$ & $1 \pm 2$ & - & $5^{ \pm 6}$ & - \\
\hline Ficus obtosiuscula (Miq.) Miq. & $3^{ \pm 5}$ & $5^{ \pm 10}$ & - & - & - & - \\
\hline Piper tuberculatum Jacq. & $5^{ \pm 6}$ & - & - & - & - & - \\
\hline Psidium guajava $\mathrm{L}$. & - & - & - & - & & $1^{ \pm 1}$ \\
\hline Rollinea emarginata Schelent & $1 \pm 1$ & $1^{ \pm 1}$ & - & - & - & - \\
\hline Sapium cf haematospermum (M.Arg.) Hub. & $1 \pm 2$ & $1^{ \pm 1}$ & - & - & - & - \\
\hline Trema micrantha (L.) Blum. & $50^{ \pm 53}$ & $7^{ \pm 7}$ & $141^{ \pm 60}$ & $108^{ \pm 60}$ & - & $1^{ \pm 1}$ \\
\hline Total arboreous & 1049 & 947 & 1889 & 673 & 33 & 36 \\
\hline Gramineous & $67^{ \pm 57}$ & $217^{ \pm 202}$ & $175^{ \pm 145}$ & $109^{ \pm 105}$ & $2431^{ \pm 557}$ & $458^{ \pm 149}$ \\
\hline Cyperaceous & $133^{ \pm 119}$ & $64^{ \pm 57}$ & $59^{ \pm 65}$ & $74^{ \pm 121}$ & $1213^{ \pm 1396}$ & $259^{ \pm 220}$ \\
\hline Others & $325^{ \pm 90}$ & $110^{ \pm 28}$ & $390^{ \pm 68}$ & $321^{ \pm 100}$ & $2634^{ \pm 1716}$ & $519^{ \pm 217}$ \\
\hline General total & 1574 & 1338 & 2513 & 1177 & 6311 & 1272 \\
\hline
\end{tabular}



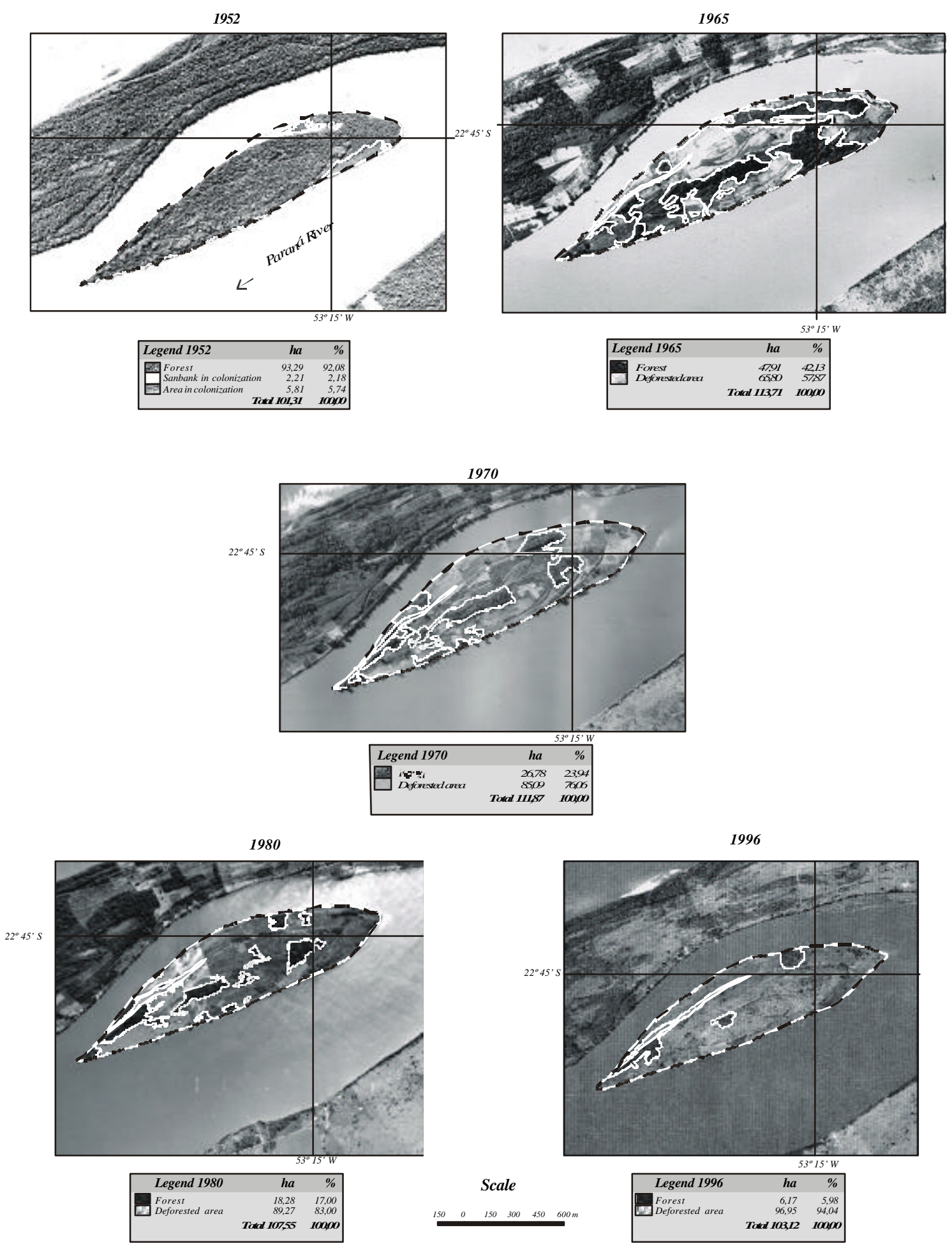

Figure 2 - Evolution of deforestation in the Porto Rico island for the years 1952, 1965, 1970, 1980 and 1996 (Campos, 1999). 
a) n. individuals

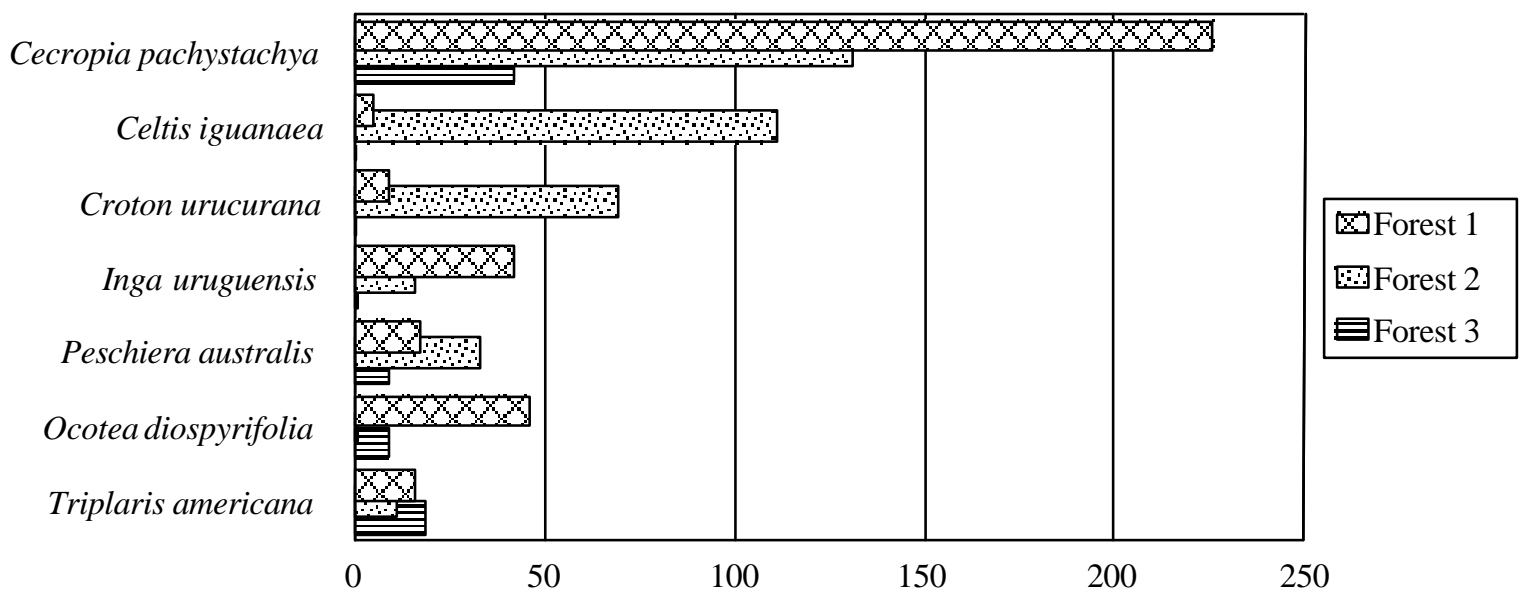

b) percentage

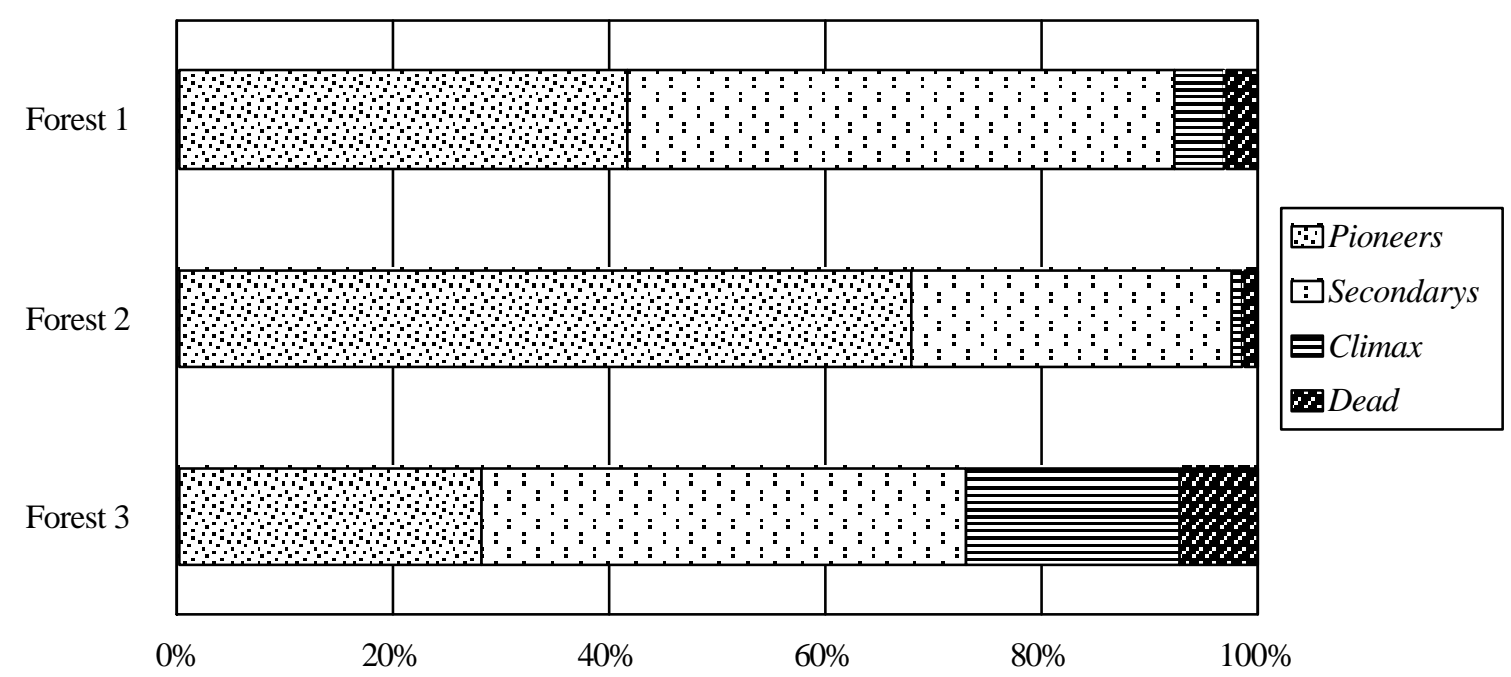

Figure 3 - Number of individuals of the principal sampled species in the phytosociological survey (a) and percentage of species of each ecological group in each forest fragment (Importande Value) (b).

With regard to arboreous species, Cecropia pachystachya had the highest participation in total seed germination in all environments in both layers (Table 3).

Croton urucurana had relatively high values in Forests 1 and 2, and Trema micrantha in Forests 1 and 3, at both depths. Celtis iguanaea was present only in Forest 2. Arboreous species were poorly represented in seed banks of the grassland.

In DCA (Fig. 5), a very clear separation occurred between Grassland and Forest fragments (axis 1 $\lambda_{1}=$ autovalues $=0.56$ ); and between Forest 3 and the other two Forest (axis $2-\lambda_{2}=0.04$ )(Fig. 5 a). Separation was determined by categories of predominant plants in the environments (Fig. 5b). 
a)

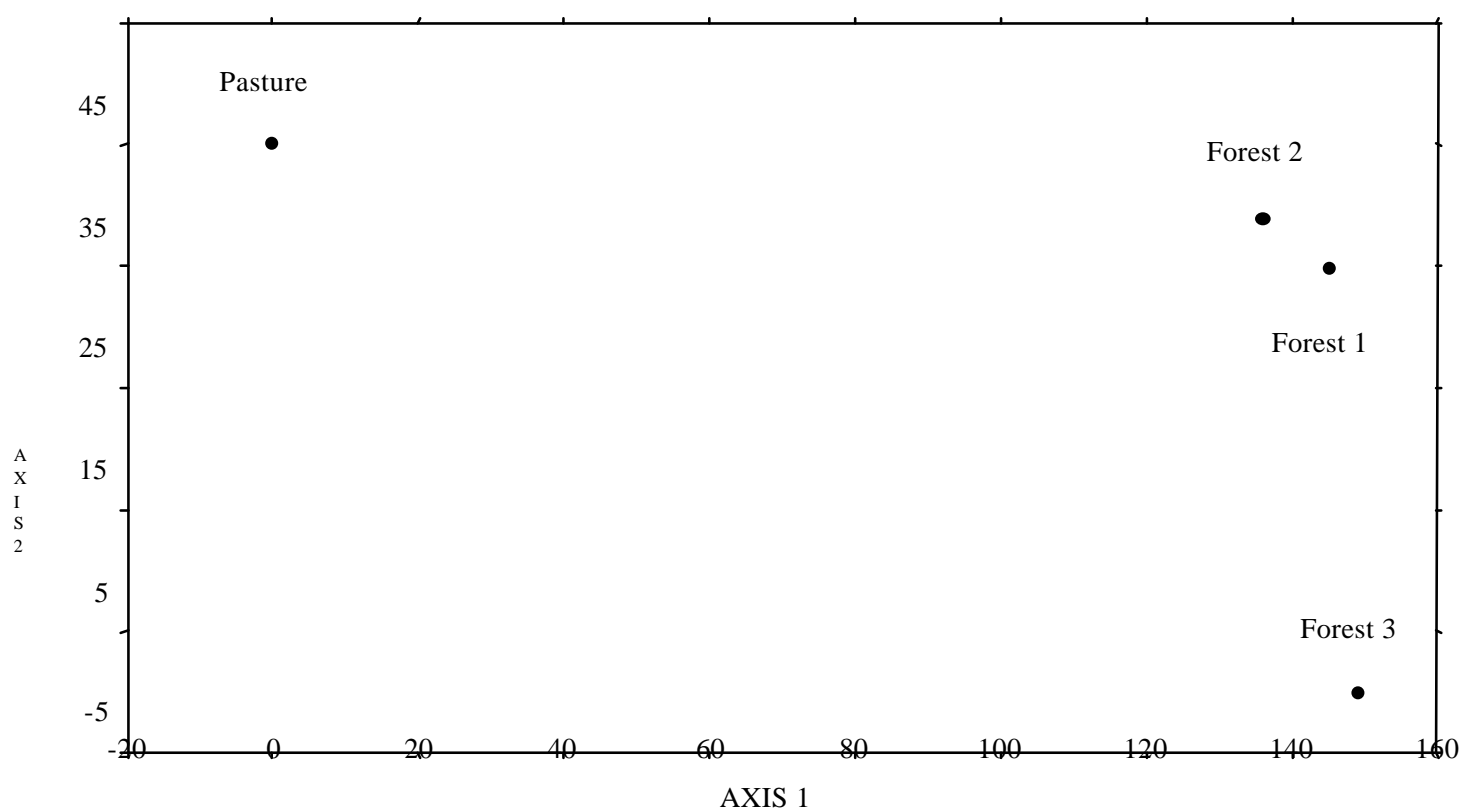

b)

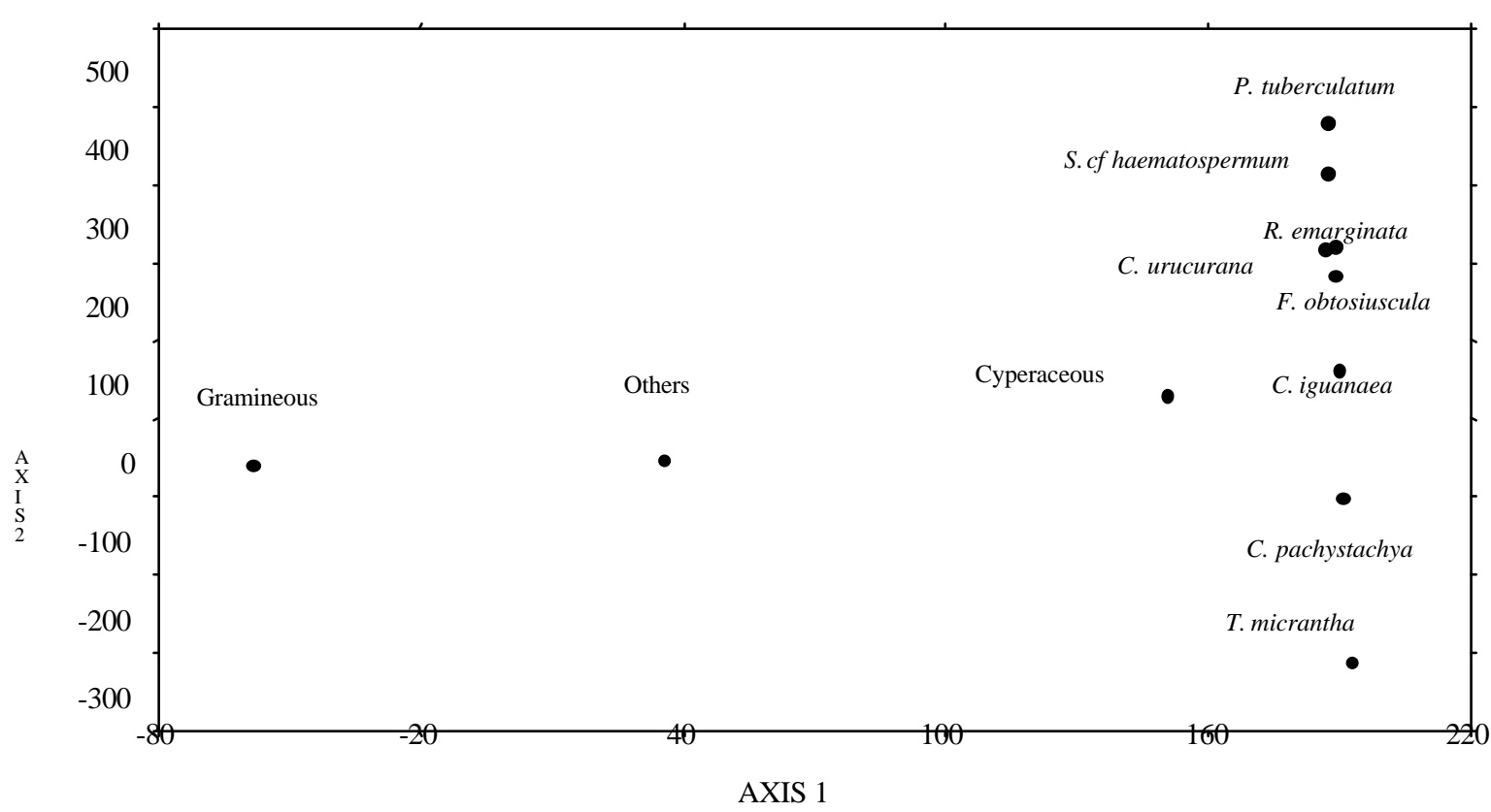

Figure 5 - Detrended Correspondence Analysis (DCA) for environments (a) and for arboreous species, gramineae, cyperaceae and others (b). 
a)

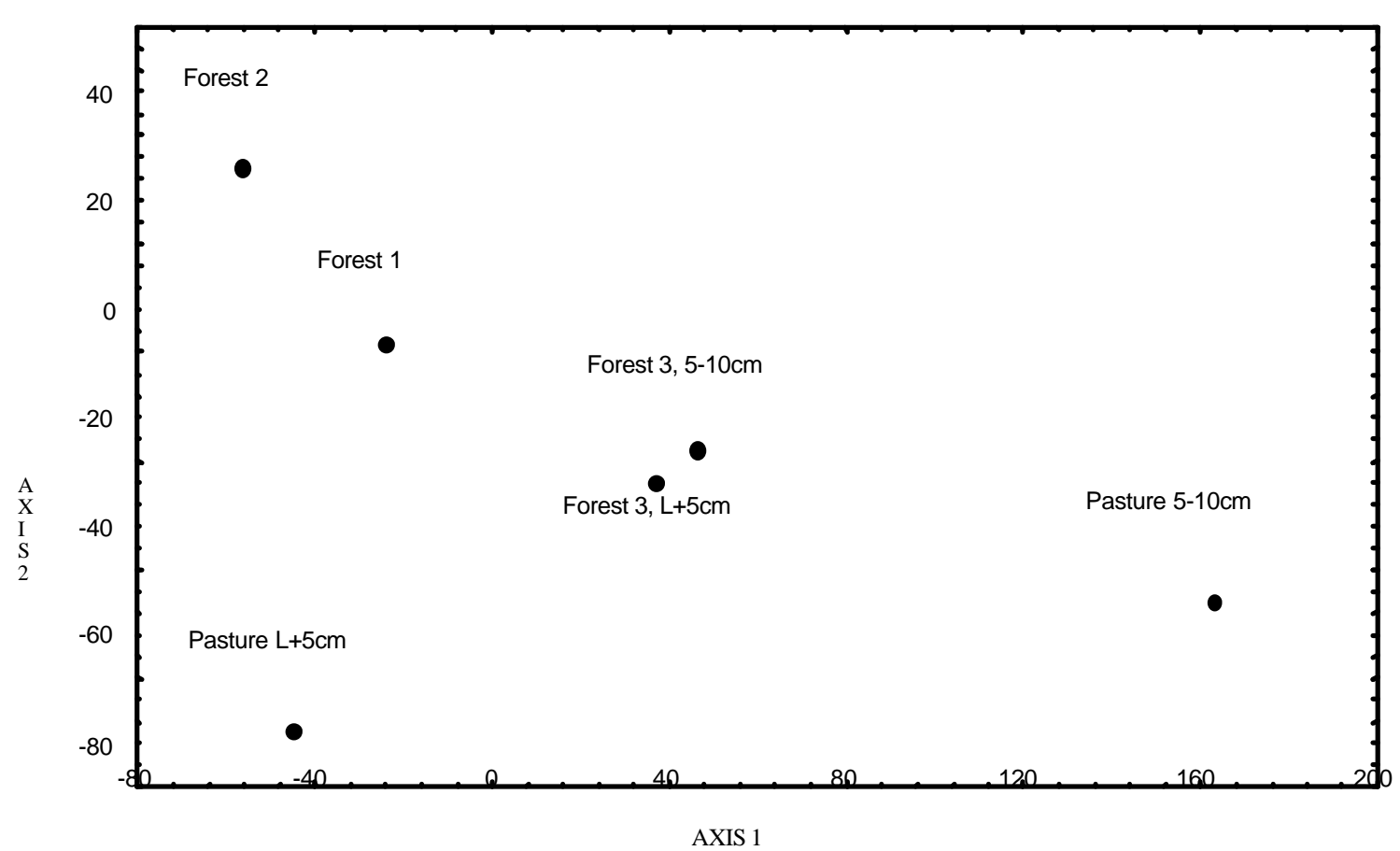

b)

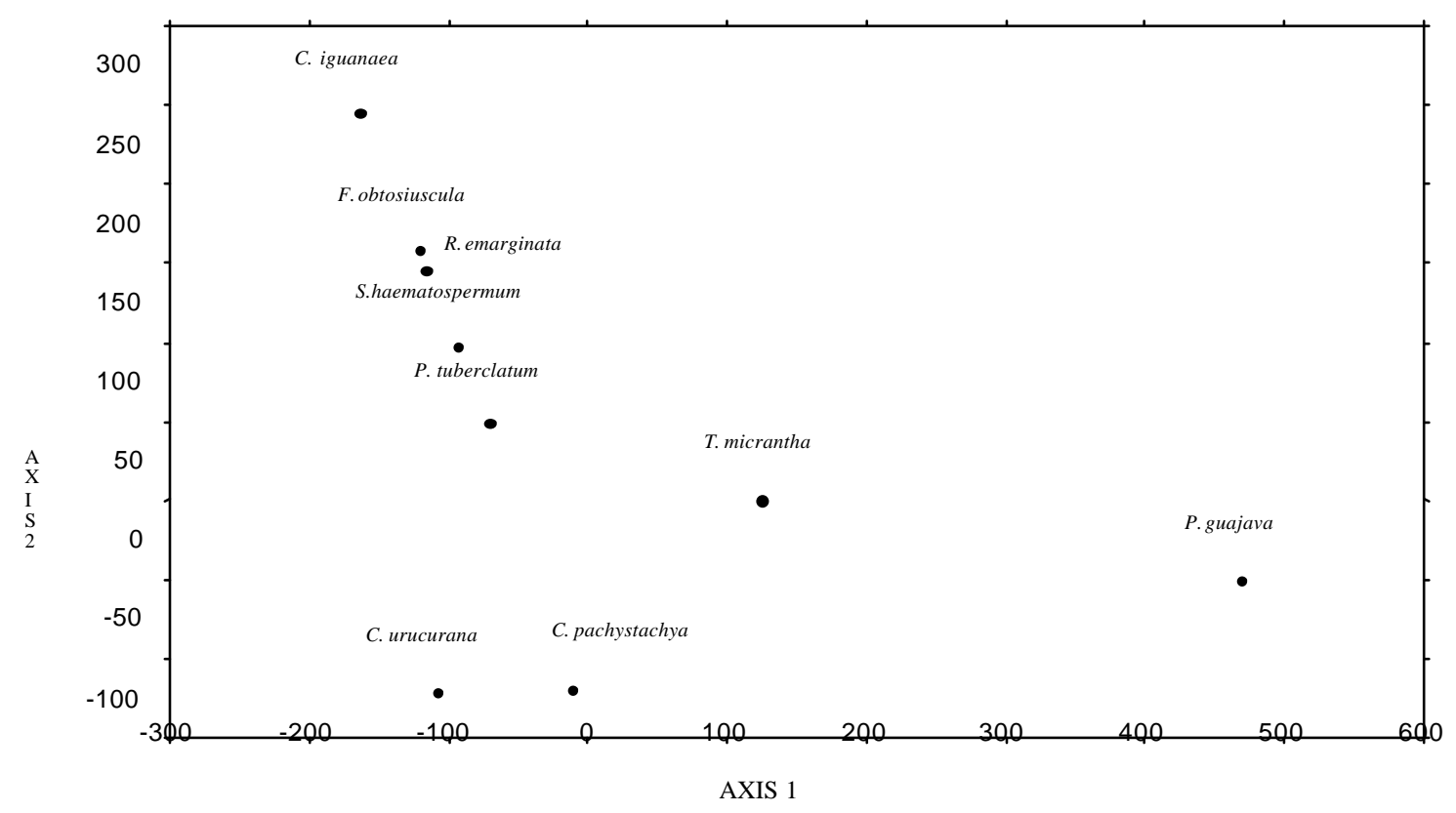

Figure 6 - Detrended Correspondence Analysis (DCA) for environments and depths (a) and for arboreous species (b). 
DCA that analyzed only the data for arboreous species (Fig. 6) showed that environments formed 4 distinct groups (axis $1 \gamma_{1}=$ autovalues $=0.35$ and axis $\left.2 \gamma_{2}=0.05\right)$. Salient distancing lied between different depths of the Grassland, which showed important differences in composition of seed bank for the two depths. This fact was not registered for Forest 3 (Fig. 6 a). Species which highly influenced definition of groups were Celtis iguanaea for Forest 2, Croton urucurana for Grassland L+5cm, Trema micrantha for Forest 3 and Psidium guajava for Grassland 5-10 cm (Fig. 6b).

\section{DISCUSSION}

The deforestation rate in Porto Rico Island is correlated to the colonization process and social transformations in the region. According to Rosa (1997), between 1962 and 1967 the islands of the Paraná river, "marginal areas" to cattle-raising because of periodic flooding, became host areas for human population expelled from the traditional rural areas during the process of transformation of local agriculture (when cattle-raising substituted coffee plantations). The period coincided with the intense rate of the island's deforestation. With the dwindling of forests on the island between 1970 and 1996, deforestation rate decreased but it continued in the continuous destructive process of the original forest (Campos, 1999). Between the $70 \mathrm{~s}$ and mid-80s, the agricultural frontier of lands with the best potential was spent and rich cattle rangers once more were interested in the islands. These were envisioned as potential areas for the expansion of their agricultural activity because of the low price of land (Rosa, 1997). From the mid-80s, people left the island and cattle was introduced. The continuous and uninterrupted process of deforestation until 1996 is explained by the expansion area for cattle-raising (Campos, 1999).

\section{Structure of forest fragments}

Cattle pasturing and hoof trampling, bush fire, the extraction and cutting of trees for various finalities and other factors caused different levels of disturbance to the remaining forests. Forest 2 was the most disturbed, with remarkable predominance of pioneer species $(67.87 \%$ of total importance value and $82 \%$ of all individuals) and lowest index of species diversity $\left(H^{\prime}=1.97\right)$. Values for this area were related to its age, since the process of primary succession started in 1952 when a sand bank was incorporated onto the island. The 45year old forest was very close to the "pioneer pattern" described by Budowski (1966), especially with regard to dominance by pioneer species of wide geographical distribution (Cecropia pachystachya, Celtis iguanaea and Croton urucurana)(Fig. 3). Using the same methodology, other areas in the upper Paraná river floodplain, also greatly disturbed and in the initial stage of succession, also presented very low diversity indices (H')(Souza et al., 1997).

Forest 1 had the highest number of species (38) when compared with the others. H' value (2.24), however, was intermediate. Disturbance level in the area probably influenced these values.

Cecropia pachystachya, predominant in the present study, belonged to the genus of pioneer species in the secondary succession of tropical forest (Budowski, 1965, 1966; Gómez-Pompa and Wiechers, 1976). Croton urucurana is considered an anthropic pioneer species and is frequent in areas with pioneer vegetation in recently formed sandbanks (Neiff, 1986). Celtis iguanaea also has the characteristics of pioneer species (Budowski, 1965; Gómez-Pompa and Wiechers, 1976; Denslow, 1980; Kageyama, 1992).

With regard to the participation of ecological groups in total importance value composition, a more equitable disturbance of values for Forest 3 has been shown. It also presented the highest values in dead trees category $(7.70 \%)$. These data, and the fact that most dead individuals belonged to the pioneer group (Cecropia pachystachya) and that the area had the highest index of species diversity $\left(H^{\prime}=2.48\right)$, suggested that Forest 3 was the most mature of the three. It seemed that it was in a more advanced stage of ecological succession.

\section{The seed bank of the Porto Rico island}

The predominance of Cecropia pachystachya in the forests of the island was reflected in the seed bank. This was highly formed by this species and almost exclusively by pioneer species in Forest 1 and 2 (99.14 and $99.36 \%$ of total of shoots, respectively) and only by pioneer species in Forest 3 and Pasture in the two depths. A single seed of Psidium guajava was found in the latter at a depth of $5-10 \mathrm{~cm}$. This species is considered an invading plant. Values confirm literature that seed banks in tropical forests have merely a small fraction of tree 
species occurring in the forests. These belonged almost exclusively to pioneer species (Harper, 1977; Whitmore, 1983, 1990; Fenner, 1985; Saulei and Swaine, 1988; Garwood, 1989; QuintanaAscencio et al., 1996).

Sapium haematospermum was not recorded on the island but its occurrence has been registered for the areas surrounding the island (Souza et al., 1997). This fact could be explained by dispersion of species or by occurrence of trees which developed previously on the spot and whose seeds were dormant in the soil from that period. The seed bank is an archive of pioneer species that previously occupied and still occupy a determined area.

Adult species in the environments are not always represented in the seed bank. The contrary is also true. Groupings by DCA together with data of phytosociological analysis of environments (Annex 1) showed that, with the exception of the two above-mentioned species, the others have a strong relation with adult species of the environments. This may be explained by the seed dispersion model where, in most species, the highest concentration of seeds occur close to the mother plant. Progressive decrease ensues in proportion to the distance from the latter.

Total density of seeds in the bank decreased with the increase of depth of soil, confirmed by other authors (Harper, 1977; Whitmore, 1983, 1990; Fenner, 1985; Garwood, 1989). In the soil's deepest level, there was a decrease of number of seeds of arboreous species in the case of the forest and a slight increase for pasture. Concerning the seeds of arboreous species, they were replaced in the Pasture seed bank with less intensity than the other categories, since they were more distant from the seed source (Whitmore, 1983). The lesser value of arboreous species registered in the upper surface of the Pasture could be explained by the depletion process of the seed in the bank (predation, germination and fire) (Harper, 1977; Quintana-Ascencio et al., 1996), which is more intense at the surface than in the deepest soil layers.

Relative to the forest areas, arboreous species of seed bank in Pasture have low values. This fact was also registered by Silvertown (1982) who suggested a long disturbance period responsible for the depletion process of the seed bank. In 1970, the Pasture area had already been deforested and used for agriculture and cattle-raising since that time. At the time of sampling, it was at least 26 years old. Long agricultural use of an area is associated with erosion and impacting of soil, oxidation of organic matter, qualitative changes in the decomposition and lixiviation process and, consequently, a process of deterioration of conditions in the establishment and growth of vegetation. The process of secondary succession is influenced by the occupation history of the site from the time of deforestation and its subsequent use (Whitmore, 1983).

\section{Potential and limitations of seed bank in the succession process}

Seeds of pioneer species are generally characterized by dormancy and longevity (Vázquez-Yanes and Orozco-Segovia, 1987; Fleming and Williams, 1990). Many authors have studied the genus Cecropia. The principal component of the seed bank of the Porto Rico island has small seeds with enforced dormancy (Vázquez-Yanes, 1976). Seeds germinate only under direct light (Vázquez-Yanes and OrozcoSegovia, 1993). According to Whitmore (1983), light, followed by temperature, in wet tropical forests is the most important factor for the start of germination.

Requirements for germination reported in literature indicated that pioneer species could germinate in the grassland (Vázquez-Yanes, 1976; Gómez-Pompa and Vázquez-Yanes, 1976; Harper, 1977; Silvertown, 1982; Cavers, 1983; Whitmore, 1983, 1990; Fenner, 1985; 1993; Fleming and Williams, 1990). Then one may ask: why seeds in the pasture do not germinate on the site? They only germinated after being collected and spread in the beds. The answer may be found in the localization of seeds in the soil cross section. The diagram developed by Harper (1977) on the population dynamics of seeds in the soil, in the floodplain should be complemented.

The origin of seeds collected for sampling could be related to: i) seeds recently arrived in the soil by seed rain and collected on the soil surface; ii) seeds which on arrival on soil were quickly removed by animals (worms, ants and other arthropods) or by rain (Harper, 1977; Fenner, 1985; Hutchings, 1986; Garwood, 1989) to deeper places; iii) remaining seeds from the seed bank of forest existing before deforestation (Harper, 1977; Whitmore, 1990); and iv) seeds which arrived by river flooding; they were covered with sediments by the flux and remained in inadequate depth for germination. Recently arrived seeds from seed rain 
form a small amount of the seed bank. Since in dispersion, a progressive decrease in seed concentration occurs in proportion to distance from sources (forests) (Cavers, 1983; Saulei and Swaine, 1988; Alvarez-Buylla and Garay, 1994) and given the proper conditions for the start of seed germination in pasture (light, temperature, humidity etc), they could quickly germinate and thus be excluded from sampling. Cecropia obtusifolia seeds are dispersed by birds and mammals. Many fall some meters away from the mother plant, even though seeds have been registered some 100 meters from source (AlvarezBuylla and Garay, 1994).

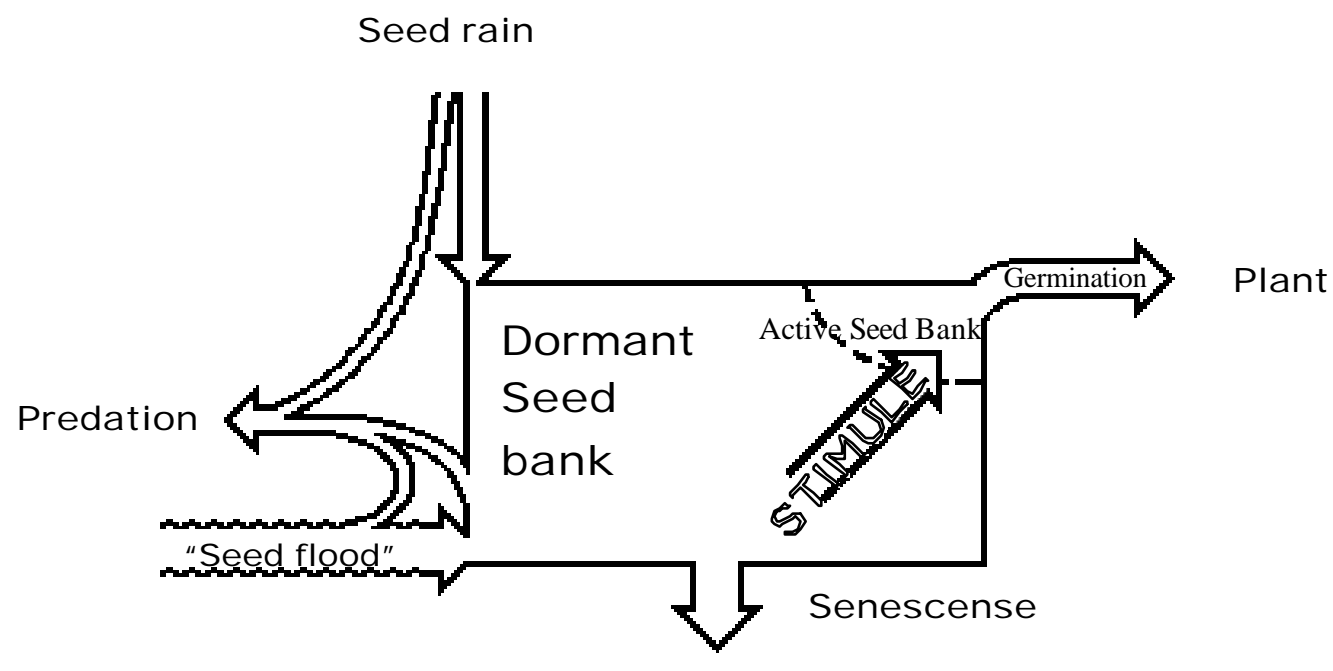

Dead

Figure 7 - Schematic diagram of population dynamics of seeds in soil for floodplains (based on Harper, 1977, with complementation).

Seeds of this species germinate quickly, between 5 to 15 days, at a temperature of $26^{\circ} \mathrm{C}$ and between 15 to 24 days at $16^{\circ} \mathrm{C}$ (Vázquez-Yanes, 1976). Alvarez-Buylla and Martinez-Ramos (1990) stated that Cecropia obtusifolia seeds have normally a short life in the soil and that the seed bank depended on the continual and uninterrupted arrival of seeds. The rate of total renovation approaches one year. In the case of Cecropia pachystachya, studies on the seed bank dynamics and on the ecology and physiology of seeds are necessary to determinate the species behavior.

The number of seeds that arrive on the soil and are removed quickly to improper depth for germination is even smaller. Besides the above-mentioned reasons, agents of seed dissemination are needed in the soil between the time of arrival and sampling. Seeds originating from the forest seed bank before deforestation is even smaller still since the former forest existing on the grassland had been destroyed some 26 years ago. During this period, the depletion process may have exhausted the seed bank.

These observations together with the fact that there were many seeds in the deeper soil levels suggested that the highest percentage of seeds in the pasture came from the periodic floods of the Paraná river. Seeds were carried (Nillson et al., 1991; Campos and Agostinho, 1997) and deposited in areas (in this case, the whole island) subjected to floods. The role of seeds in the soil and in the renewal of local vegetation depended on the depth in which they germinated and on the rate they were brought to the surface. The germination capacity of seeds decreased with depth and was influenced by the type of soil and seed size (Garwood, 1989). According to Harper (1977), most seeds on the soil surface deteriorated and died. 
Since seeds of arboreous species in pasture are small, with low energetic reserve, capable only of germinating in shallow soil (Harper, 1977; Vázquez-Yanes, 1976; Vázquez-Yanes and Orozco-Segovia, 1987) and since soil in the island is "heavy" type (Wet Glazed Hydromorphic, slightly Wet and Cambisol) (Embrapa/Iapar, 1984) with intensive hoof trampling, the inability of the seeds to furnish the immediate natural reestablishment of vegetation has been suggested. With the ceasing of cattle hoofing in the area, the immediate reestablishment of vegetation would be more conditioned by the arrival of other seeds to the site (by rain and flood process) than by the seeds existent in the bank.

\section{CONCLUSIONS}

Due to historical disturbances, the remaining forests on the island, especially Forest 1 and 2, were taking the inversion in the successional process ("retrocession process"): secondarization in the first place, "pioneerization" in the second and disappearance in the third. As seen above, this is due to continuous direct or indirect impacts produced especially by cattle-raising. In the process of recovering of area, one should be convinced that the remnants of these forests are important sources of seeds for the natural reestablishment of the vegetation.

Regarding to the seed bank, one's conclusion, identical to that of Quintana-Ascencio et al. (1996), would be that the persistence and the expansion of pasture areas favor the severe impoverishment of the flora of the seed bank. The physical characteristics of seeds found in the bank, their site in the soil and the characteristics of the soil constituting the pasture area suggest the inability of these seeds to reestablish the vegetation immediately. This study indicates that immediate reestablishment is more conditioned to the process of the arrival of other seeds to the area (by rain and "flood seed") than by the stock of seed in the bank.
The role of these seeds in the near future should not be discarded towards the maintenance of the diversity and the genetic structure of the species. If natural regeneration occurs from the seed bank, it should be emphasized that the future forest would not have the same role as the former one. This is due to the low diversity of species in the seed bank and to biotic and abiotic changes in the area.

\section{RESUMO}

Objetivando avaliar o potencial de regeneração de florestas a partir do banco de sementes do solo da ilha Porto Rico $\left(53^{\circ} 15^{\prime} \mathrm{W}\right.$ e $\left.22^{\circ} 45^{\prime} \mathrm{S}\right)$, foi estudado o processo histórico de desflorestamento, identificado e dimensionado os fragmentos florestais remanescentes, avaliada a estrutura da vegetação arbórea e a composição do banco de sementes das florestas e das pastagens da ilha. Os resultados apontam um rápido e agressivo processo de desflorestamento com níveis críticos de cobertura florestal, onde remanescem 3 fragmentos, que representam apenas 5,98\% da superfície total da ilha. As perturbações ocasionadas pelo gado criado extensivamente na ilha promovem um contínuo processo de degradação desses fragmentos (sucessão retrogressiva). A expansão das áreas com pastagem promove um empobrecimento severo da flora do banco de sementes e, aliado a compactação do solo e às características das sementes das espécies arbóreas existentes no banco, sugere que o restabelecimento imediato da vegetação está mais condicionado ao processo de chegada de sementes ao local (chuva e enxurrada de sementes) do que ao estoque de sementes existentes no banco. 
Annex 1 - List of species sampled in the phytosociological survey, including the "dead trees" category, in the fragments of the Semideciduous Seasonal Alluvial Forest (Forest 1; Forest 2; Forest 3) in decreasing total of individuals (n), with their respective importance values (IV) and classification in ecological groups $(\mathrm{EG})(\mathrm{P}=$ pioneers; $\mathrm{S}=$ secondary; $\mathrm{C}=$ climax) in the Porto Rico island, Brazil.

\begin{tabular}{|c|c|c|c|c|c|c|c|c|}
\hline \multirow[t]{2}{*}{ Species/Dead } & \multirow[t]{2}{*}{ EG } & \multirow{2}{*}{$\begin{array}{c}\text { Forest } \\
\mathbf{n}\end{array}$} & \multirow{2}{*}{$\frac{1}{\text { IV }}$} & \multicolumn{2}{|c|}{ Forest 2} & \multicolumn{2}{|c|}{ Forest 3} & \multirow{2}{*}{$\begin{array}{c}\text { Total } \\
\mathbf{n} \\
\end{array}$} \\
\hline & & & & $\mathbf{n}$ & IV & $\mathbf{n}$ & IV & \\
\hline Cecropia pachystachya Trec. & $\mathrm{P}$ & 226 & 107,03 & 131 & 86,60 & 42 & 58,79 & 399 \\
\hline Celtis iguanaea (Jacq.) Sargent. & $\mathrm{P}$ & 5 & 2,14 & 111 & 55,14 & - & - & 116 \\
\hline Croton urucurana Baill. & $\mathrm{P}$ & 9 & 6,86 & 69 & 40,28 & - & - & 78 \\
\hline Inga uruguensis Hook et Arn. & $S$ & 42 & 28,49 & 16 & 25,08 & 1 & 1,89 & 59 \\
\hline Tabernaemontana catharinensis A. DC. & S & 17 & 8,89 & 33 & 21,07 & 9 & 13,44 & 59 \\
\hline Ocotea diospyrifolia (Meissn.) Mez. & $S$ & 46 & 26,03 & 1 & 1,02 & 9 & 15,32 & 56 \\
\hline Triplaris americana $\mathrm{L}$. & S & 16 & 8,18 & 11 & 8,50 & 19 & 26,57 & 46 \\
\hline Coussarea platyphylla M. Arg. & $\mathrm{C}$ & 4 & 1,89 & - & - & 41 & 36,20 & 45 \\
\hline Unonopsis lindmanii R. G. Fr. & $\mathrm{C}$ & 3 & 1,79 & - & - & 27 & 26,21 & 30 \\
\hline Dead Trees & - & 13 & 9,12 & 4 & 4,21 & 11 & 23,15 & 28 \\
\hline Allophyllus edulis (A.St. Hil.) Radlk. & S & 24 & 9,63 & - & - & 3 & 3,20 & 27 \\
\hline Sloanea garckeana K.Schum. & S & 11 & 6,58 & 14 & 11,79 & 1 & 1,56 & 26 \\
\hline Picramnia selowii Planch. & $S$ & 15 & 6,40 & 2 & 2,04 & 2 & 3,30 & 19 \\
\hline Albizzia hassleri (Chodat) Burr. & $S$ & 7 & 4,85 & 1 & 1,01 & 9 & 14,38 & 17 \\
\hline Piper tuberculatum Jacq. & $\mathrm{C}$ & 12 & 6,42 & 2 & 2,05 & - & - & 14 \\
\hline Protium heptaphyllum Aubl. March. & S & - & - & - & - & 13 & 15,73 & 13 \\
\hline Zygia cauliflora (Willd.) Killip. & S & 10 & 5.66 & - & - & 3 & 4,79 & 13 \\
\hline Casearia lasyophylla Eichler & $S$ & 8 & 4,77 & 4 & 4,15 & - & - & 12 \\
\hline Genipa americana $\mathrm{L}$. & S & 9 & 6,05 & - & - & 3 & 6,70 & 12 \\
\hline Nectandra falcifolia (Nees.) Cast. ex Mez. & $S$ & 4 & 2,72 & 8 & 9,83 & - & - & 12 \\
\hline Eugenia florida DC. & $\mathrm{S}$ & 9 & 570 & - & - & 2 & 3,18 & 11 \\
\hline Ficus obtusiuscula (Miq.) Miq. & S & 3 & 9,78 & 8 & 17,81 & - & - & 11 \\
\hline Psychotria carthagenensis Jacq. & $\mathrm{C}$ & 9 & 4,18 & -1 & 1,02 & - & - & 10 \\
\hline Trichilia palida $\mathrm{Sw}$. & $S$ & 3 & 1,56 & - & - & 7 & 8,60 & 10 \\
\hline Sapindus saponaria $\mathrm{L}$. & $\mathrm{S}$ & 9 & 6,79 & - & - & 1 & 2,57 & 9 \\
\hline Pouteria glomerata (Miq.) Radlk. & $S$ & 5 & 2,03 & - & - & 2 & 3,27 & 7 \\
\hline Xylosma glaberrimum Sleumer & S & 4 & 2,49 & 2 & 2,05 & 1 & 2,07 & 7 \\
\hline Undetermined sp 1 & $S$ & - & - & - & - & 6 & 8,74 & 6 \\
\hline Casearia sp 1 & $S$ & 5 & 2,91 & - & - & - & - & 5 \\
\hline Pouteria torta (Mart.) Radlk. & $S$ & - & - & - & - & 4 & 6,01 & 4 \\
\hline Chusquea sp & S & 1 & 0,90 & - & - & 2 & 4,79 & 3 \\
\hline Flacourtiaceae sp 1 & $S$ & - & - & 3 & 3,14 & - & - & 3 \\
\hline Guarea macrophilla Vahl. & $S$ & 1 & 0,69 & - & - & 2 & 4,33 & 3 \\
\hline Undetermined sp 2 & $S$ & 3 & 1,23 & - & - & - & - & 3 \\
\hline Erythroxylum anguifugum Mart. & S & 2 & 1.37 & - & - & - & - & 2 \\
\hline Ficus gomelleira Kth. Et Bouché & $S$ & 1 & 0,97 & - & - & 1 & 1,99 & 2 \\
\hline Rollinia emarginata Schlent & S & 1 & 0,68 & 1 & 1,05 & - & - & 2 \\
\hline Sapotaceae & $S$ & 2 & 1.57 & - & - & - & - & 2 \\
\hline Andira fraxinifolia Benth. & $S$ & 1 & 0,70 & - & - & - & & 1 \\
\hline Casearia $\operatorname{sp} 2$ & S & 1 & 0,66 & - & - & - & - & 1 \\
\hline Colubrina retusa (Pittier) Cowan & $S$ & 1 & 0,70 & - & - & - & - & 1 \\
\hline Flacourtiaceae sp2 & $S$ & - & - & - & - & 1 & 1,63 & 1 \\
\hline Peltophorum dubium (Spreng.) Taub. & $S$ & - & - & - & - & 1 & 1,60 & 1 \\
\hline Rapanea sp. & $S$ & - & - & 1 & 1,02 & - & - & 1 \\
\hline Rollinia silvatica (St. Hil.) Mart. & $S$ & 1 & 0,85 & - & - & - & - & 1 \\
\hline Vitex montevidensis Cham. & S & - & - & 1 & 1,14 & - & - & 1 \\
\hline Xylosma cf venosum N.E. Brown & $\mathrm{S}$ & 1 & 0,66 & - & - & - & - & 1 \\
\hline
\end{tabular}




\section{REFERENCES}

Agostinho, A. A. and Zalewski, M. (1996), A planície alagável do alto rio Paraná: importância e preservação. Maringá - PR : EDUEM.

Alvarez-Buylla, E. R. and Martínez-Ramos, M. (1990), Seed bank versus seed rain in the regeneration of a tropical pioneer tree. Oecologia, 84, 314-325.

Alvarez-Buylla, E. R. and Garay, A. A. (1994), Population genetic structure of Cecropia obtusifolia: a tropical pioneer tree species. Evolution, 48 : (2), 437-453.

Alvarez-Buylla, E. R.; Chaos, A., Piñero, D. and Garay, A. A. (1996), Demographic genetics of a pioneer tropical tree species: pacth dynamics, seed dispersal, and seed banks. Evolution, 50 : (3), 1155-1166.

Budowski, G. (1963), Forest succession in tropical lowlands. Turrialba, 13 : (1), 42-44.

Budowski, G. (1965), Distribution of tropical american rain forest species in the light of sucessional processes. Turrialba, 15, 40-42.

Budowski, G. (1966), Los bosques de los trópicos húmedos de América. Turrialba, 16 : (3), 278-285.

Campos, J. B. (1999), Spatial and multi-temporal analysis of deforestation and quantification of the remnant forests on Porto Rico island, Paraná, Brazil. Brazilian Archives of Biology and Technology, 42 : (1), 91-100.

Campos, J. B. and Agostinho, A. A. (1997), Corredor de fluxo de biodiversidade do rio Paraná: uma proposta para a proteção ambiental de ecossistemas ameaçados. In: Congresso Brasileiro de Unidades de Conservação (1) Anais...Curitiba. pp. 645-657.

Campos, J. B.; Dilger, R. and Weidlich, J. T. M. (1997), Reserva de la biosfera como estrategia para protection del ultimo remanente del rio Paraná en Brasil. UNESCO - MaB. Perspectivas Sur - Sur, 4, 17-18.

Campos, J. B., Romagnolo, M. B. and Souza, M. C. (2000), Structure, composition and spatial distribution of tree species in a remnant of the semideciduous seasonal alluvial forest of the Upper Paraná River Floodplain. Brazilian Archives of Biology and Technology, 43 : (1).

Cavers, P. B. (1983), Seed demography. Canadian Journal of Botany, 61 : (12), 3578-3590.

Denslow, J. S. (1980), Gap partitioning among tropical rainforest tree. Tropical Succession, 47, 47-55.

EMBRAPA/IAPAR (1984), Serviço Nacional de Levantamento e Conservação de Solos, Rio de Janeiro, RJ. Levantamento e reconhecimento dos solos do Estado do Paraná. Curitiba, 1984. 2v.: il. (Embrapa - SNLCS. Boletim técnico; n. 27).

Fenner, M. (1985), Seed Biology. Chapman and Hall, London.

Fleming, T. H. and Willians, C. F. (1990), Phenology, seed dispersal, and recruitment in Cecropia peltata (Moraceae) in Costa Rican tropical dry forest. Journal of Tropical Ecology, 6, 163-178.
Garwood, N. C. (1989), Tropical soil seed bank: a review. pp.149-209. In: Leck, M. A.; Parker, V. T. and Simpson, R. L. (eds.), Ecology of soil seed bank.. Academic Press, San Diego.

Gómez-Pompa, A. and Vázquez-Yanes, C. (1976), Estudio sobre sucesión secundaria en los tropicos cálido-húmedos: el ciclo de vida de las especies secundarias. In: Gómez-Pompa, A.; Vásquez-Yanes, C.; Rodríguez del Amo, S. and Butanda-Cervera, A. (eds.). Regeneracion de selvas. Mexico : C.E.C.S.A. pp. 579-593.

Guevara S. S.; Gómez-Pompa, A. (1976), Determinación del contenido de semillas en muestras de suelo superficial de una selva tropical de Vera Cruz, México. In: Gómez-Pompa, A.; Vásquez-Yanes, C.; Rodríguez del Amo, S. and Butanda-Cervera, A. (eds.). Regeneracion de selvas. Mexico : C.E.C.S.A. pp. 203-232.

Harper, J. L. (1977), Population of biology plants. London : Academic Press.

Hill, M O. and Gauch, H. G. T. (1980), Detrended Correspondence Analysis: an improved ordenation technique. Vegetatio, 4, 47-58.

Hutchings, M. L. (1986), Plant population biology. In: Moore, P. D. and Chapman, S. B. (eds.). Methods in plant ecology. Blackwell, Sientific, Oxford. pp. 77-436.

Junk, W. J.; Bayley. P. B. and Sparks, R. E. (1989), The flood pulse concept in river floodplain systems. Can. Spec. Publ. Fish. Aquat. Sci., 106, 110-127.

IBGE - Fundação Instituto Brasileiro de Geografia e Estatística. (1992), Manual técnico da vegetação brasileira. Rio de Janeiro : IBGE. (Série Manuais Técnicos em Geociências; 1).

Kageyama, P. Y.; Equipe Técnica da CESP (1992), Recomposição da vegetação com espécies arbóreas nativas em reservatórios de usinas hidrelétricas da CESP. Série técnica IPEF, 8 : (25), 1-43.

Mateucci, S. and Colma, A. (1982), Metodologia para el estudio de la vegetación. Secretaria general de la Organización de los Estados Americanos. Washington D.C. : OEA.

Müeller-Dombois, D. and Ellenberg, H. (1974), Aims and methods of vegetation ecology. John Wiley and Sons. New York.

Neiff, J. J. (1986), Las grandes unidades de vegetacion y ambiente insular del rio Paraná en el tramo Candelaria - Ita Itabe. Revista de la Associacion de Ciencias Naturales del Litoral, 17 : (11), 7-13.

Neiff, J. J. (1990), Ideas para la interpretación ecologica del Paraná. Interciencia, 15, 424-441.

Nilsson, C.; Gardflell, M. and Grelsson, G. (1991), Importance of hydrochory in structruring plant communities along rivers. Canadian Journal of Botany, 69, 2631-2633. 
Quintana-Ascencio, P. F.; González-Espinosa, M.; Ramírez-Marcial, N.; Domínguez-Vázquez, G. and Martínez-Icó, M. (1996), Soil seed bank and regeneration of tropical rain forest from milpa fields at the Selva Lacandona, Chiapas, Mexico. Biotropica, 28 : (2), 192-219.

Rosa, M. C. (1997), Processo de ocupação e situação atual. In: Vazzoler, A. E. A. M.; Agostinho, A. A. and Hahn, N. S. (eds.), A planície de inundação do alto rio Paraná: aspectos físicos, biológicos e socioeconômicos. EDUEM : Nupélia, Maringá. pp. 371-394.

Saulei, S. M. and Swaine, M. D. (1988), Rain forest dynamics during sucession at Gogol, Papua New Guinea. Journal of Ecology, 76, 1133-1152.

Silvertown, J. (1987), Introduction to plant population ecology. Longman Scientific and Tecnical, London.

Souza, M. C.; Cislinski, J. and Romagnolo, M. B. (1997), Levantamento florístico. In: Vazzoler, A. E. A. M., Agostinho, A. A. and Hahn, N. S. (eds.), A planície de inundação do alto rio Paraná: aspectos físicos, biológicos e socioeconômicos. EDUEM : Nupélia, Maringá. pp. 344-368.

Vázquez-Yanes, A. (1976), Estudios sobre la ecofisiologia de la germinación en una zona cálidohúmeda de México. In: Gómez-Pompa, A.; VásquezYanes, C.; Rodríguez del Amo, S. and ButandaCervera, A. (eds.), Regeneracion de selvas. C.E.C.S.A. Mexico. pp. 279-387.
Vázquez-Yanes, A; Orozco-Segovia, A. (1987), Fisiologia ecológica de semillas en la Estación de Biologia Tropical "Los Tuxtlas", Vera Cruz, México. Rev. Biol. Trop., 35 : (1), 85-96.

Vázquez-Yanes, A; Orozco-Segovia, A. (1993), Pattern of seed longevety and germination in the tropical rainforest. Annu. Rev. Ecol. Syst., 24, 69-87.

Whitmore, T. C. (1983), Secundary sucession from seed in tropical rain forest. Forestry Abstract, 44, 767-779.

Whitmore, T. C. (1990), An introduction to tropical rain forest. Oxford : Oxford University Press.

Received: July 27, 2001; Revised: October 01, 2002; Accepted: May 02, 2003. 